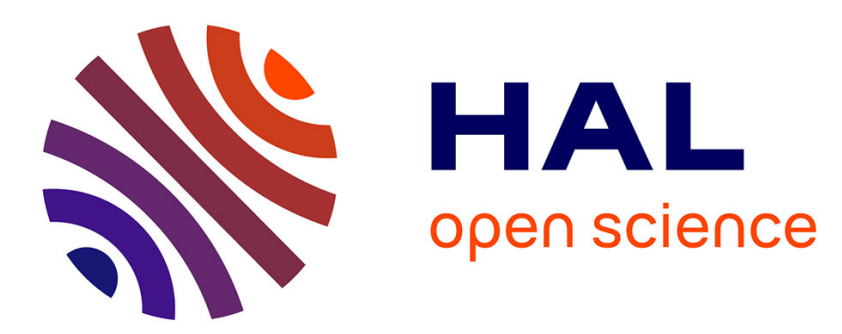

\title{
Student satisfaction with distance education during the COVID-19 first-wave: A cross-cultural perspective
}

\author{
Seeun Jung, Radu Vranceanu
}

\section{To cite this version:}

Seeun Jung, Radu Vranceanu. Student satisfaction with distance education during the COVID-19 first-wave: A cross-cultural perspective. 2020. hal-02977873

\section{HAL Id: hal-02977873 \\ https://essec.hal.science/hal-02977873}

Preprint submitted on 26 Oct 2020

HAL is a multi-disciplinary open access archive for the deposit and dissemination of scientific research documents, whether they are published or not. The documents may come from teaching and research institutions in France or abroad, or from public or private research centers.
L'archive ouverte pluridisciplinaire HAL, est destinée au dépôt et à la diffusion de documents scientifiques de niveau recherche, publiés ou non, émanant des établissements d'enseignement et de recherche français ou étrangers, des laboratoires publics ou privés. 


\section{ESSEC \\ BUSINESS SCHOOL}

\section{STUDENT SATISFACTION WITH DISTANCE}

EDUCATION DURING THE COVID-19 FIRST-WAVE:

A CROSS-CULTURAL PERSPECTIVE

SeEun Jung

Radu Vranceanu

ESSEC RESEARCH CENTER

WORKING PAPER 2007

OCTOBER 2020 


\title{
Student satisfaction with distance education during the COVID-19 first-wave: A cross-cultural perspective
}

\author{
SeEun Jung \& Radu Vranceanu ${ }^{+}$
}

October 2020

\begin{abstract}
This research note reports results of a survey on student satisfaction with distance education in Korea and France as implemented in May 2020 on 510 respondents. At that time, both countries closed the facilities of higher education institutions and imposed the extensive use of on-line education. A majority of French students express a preference for in-class teaching compared with on-line teaching, while preferences of the Korean students are more balanced. On average, Korean students express higher satisfaction with online teaching compared to French students. Women students also report higher satisfaction scores. The COVID-19 stress is negatively related to satisfaction with online teaching in Korea, but not in France.

JEL Classification: I23; I28; I19

Keywords: Distance education, Student satisfaction, Synchronous teaching, COVID-19 stress.
\end{abstract}

\section{Introduction}

Distance education (DE), defined as an educational experience where instructors and learners are separated in time and space (Keegan (2002)), has been present in the higher education landscape for decades. While in its early years DE comprised essentially correspondence courses, in the last thirty years the Internet revolution pushed this service toward the production of online content and learning interaction.

One can distinguish between asynchronous learning, through which students have access to online resources such as short videos, MOOCs, etc. in an autonomous way, and synchronous

\footnotetext{
Department of Economics, Inha University, 100 Inharo, Namgu, Incheon, South Korea. Email: jse@inha.ac.kr

${ }^{\dagger}$ Corresponding Author: Department of Economics, ESSEC Business School and THEMA, 1 Avenue Bernard Hirsh, 95021, Cergy, France. Email: vranceanu@essec.edu

The authors would like to thank Juyoung Cheong, Dong Ook Choi, Delphine Dubart, Kwangki Kim, MarieNoelle Koebel, Sophie Magnanou, Emmanuelle le Nagard, Ilsoon Shin, Angela Sutan for their remarks and suggestions, and their support in the implementation of the survey.
} 
instruction through which teachers and learners meet online for a session at a predetermined time (Fidalgo et al. (2020)).

Synchronous instruction has developed along the lines of existing video-conference systems. The most valuable feature of the new systems was the dialogue or interaction between the teacher and the students, or among the students, referred to as synchronous and interactive online education (SIOE). With the progress of Internet bandwidth and data compression technology, the quality of synchronous and interactive instruction greatly improved, by allowing simultaneous contacts for larger groups, and for a more fluid transfers of sound and video images between the participants. For sure, there is substantial room for further improvements: today "Zoom fatigue" due to communication micro-lags, and the "life behind the screen" has been criticized as a major flaw of this approach (Fosslien and Duffy (2020)). Synchronous teaching can be recorded in a cloud, which provides for an interesting asynchronous complement. Software initially developed for the purpose of video conferences become an important vector of SIDE development, to mention only Microsoft Team, Professional Skype, Google Meet, and Zoom.

Not a long time ago many observers were betting on the asynchronous DE as the future of higher education. ${ }^{1}$ SIOE was seen as for sure a fancy device, but not yet mature for mass applications. In "normal times", SIOE would have followed the standard technology adoption path, with some shy, then accelerating dynamic, and probably deemed to disappear when a more efficient system would become available. The major catastrophe of the COVID-19 pandemic turned down all these predictions. The first wave of the COVID-19 pandemic started in the late 2019 in Wuhan, China and then spread globally, with a devastating impact on the planet.

To slow down the unexpected and rapid propagation of the virus, in early 2020 many governments imposed stringent social and physical distancing measures. Korea provided a leading example of good management of the crisis, with self-imposed measure of social distancing, the widespread use of masks and generalized testing. However, many countries were unprepared to fight such a powerful epidemic and had no choice but to resort to lockdowns that limited people mobility to the bare economic necessity.

Governments in a large majority of countries, including Korea and France, decided to close the brick and mortar facilities of the schools. On short notice, teachers were asked to switch from a traditional teaching way, as performed for at least two centuries, to an untested online teaching mode. In France the change was largely unprepared, many professors having to rely on their own material resources and preexisting computer skills to manage this transition. Students and pupils in schools meet the same difficulties. In less than three days, parents had to become education coaches, with significant variation in the ability to adapt to this unexpected mission, depending on their educational background, number of children and spare time.

So distance education appeared as a "miracle" efficient solution to continue education during the lockdowns and under strict physical distancing, with thousands of teachers and maybe millions of students throughout the world being obliged to switch, at short notice, to distance education. The most appealing, and dominant system was SIOE.

\footnotetext{
${ }^{1}$ An an example of such optimistic beliefs, Garrison (2000) once stated: "Asynchronous collaborative learning may well be the defining technology of the postindustrial era of distance education." (p.12).
} 
This research note presents the results from a survey on student satisfaction with SIOE, carried out during the strict lockdown period of France, in Mai 2020, with undergraduate students in France and Korea. ${ }^{2}$ The analysis aims to provide a comparison of learning effectiveness and satisfaction levels with online education between the two countries, and study factors that might contribute to the satisfaction level and the stated preference for distance education relative to in-classroom teaching.

The two countries are a meaningful basis for cross-cultural studies: their level of economic development is relatively similar and their population sizes are close; at the same time, they are representative of the Western and Asian cultures along Hoofstede multi-dimensional approach (Hofstede (2001)). ${ }^{3}$ Data downloaded on October 13, 2020 from Hofstede Insights show an individualism index of 71 for France, and 18 for Korea. ${ }^{4}$. Long-term orientation is also higher in Korea compared to France, while the differences are much smaller on all the other dimensions of the cultural orientation.

Other studies have investigated satisfaction with online teaching. ${ }^{5}$ A survey and metaanalysis of 24 studies by Allen et al. (2002) reveal that, at that period, students slightly prefer in-class courses to distance education; furthermore, they do not attach positive value to classroom interactions. Summers et al. (2005) show that, controlling for the experience of the professor and evaluation method, students exposed to online courses were less satisfied than their campus-based peers. Wei and Chou (2020) use survey data to estimate a structural equation model to analyze factors that explain satisfaction with online classes. They find that students' computer/Internet self-efficacy and motivation for learning exerted a direct, positive effect on their online discussion score and course satisfaction.

However, there is a major difference between these studies and ours. In the past, schools (and maybe students too) had the choice between on-campus and on-line instruction and use to test freely various DE methods. In the COVID-19 period, neither teachers nor students had other choice but to adopt the online technology. A majority of schools chose spontaneously the SIOE model, although they were experimenting for many years with asynchronous DE. This choice reveals that the value proposition of synchronous interactive online instruction was better fitted to the need of massive online education than the asynchronous format. This "external justification" or "scapegoat role" of the epidemic to adopt SIOE might have had a positive impact on student satisfaction.

\section{Data collection}

The data was collected by means of an online survey, administered in early May 2020, on undergraduate students in two business schools in France (one in the Ile-de-France region, the

\footnotetext{
${ }^{2}$ On May 31st 2020, the Johns Hopkins Coronavirus Research Center reported a cumulative 28800 case fatalities in France.

${ }^{3}$ Jung and Vranceanu (2019) provide an analysis of cross-cultural differences in the attitude toward competing and further discuss the cultural differences of Korean and French students

${ }^{4}$ See www.hofstede-insights.com/product/compare-countries/

${ }^{5}$ See Weerasinghe and Fernando (2017) for a survey on the literature on student satisfaction in general.
} 
other in Burgundy regions $)^{6}$ and one University in Incheon, South Korea.

A majority of students (98\%, 235 students out of 239) were following more than 4 classes online at the time the survey was implemented. Most of the classes were delivered through Zoom and Google Meeting in France (with the possibility of recording the course), Zoom and recorded video via Youtube or LMS (Learning Management System) in Korea.

Korean students were two year older on average; in France, 59 per cent of the respondents were women, and 44 per cent of the respondents were women in Korea.

We also rely on survey questions to determine the degree of overconfidence and tolerance to risk, using for the latter the self-reported measure of the eagerness to accept risks as introduced by Dohmen et al. (2011). A higher level indicates a higher degree of overconfidence, and a better tolerance to risk.

Also, the survey elicits their "cultural orientation" using individualistic and collectivist scores. For so doing, we use four "horizontal" items from the individualism/collectivism scale as developed by Triandis and Gelfland (1998). The two individualism items are "I rely on myself most of the time; I rarely rely on others" and "I often do "my own thing". The two collectivism items are "The well-being of my coworkers is important to me" and "To me, pleasure is spending time with others". Our narrow scale sums the scores with the reverse sign for the individualism score. The maximum score of one indicates an extremely collectivist stance, the lowest (zero) score, an extremely individualist stance.

An important question elicited their ability to fix simple technical problems (computer selffix), which is probably related to a student's broader interest in computer based technology. Other measures were the time they spent - before the pandemic - on computer games (time-use game) and also on cellular phones (time-use online), as proxies for online habits and resilience.

The self-reported time used per week for sport activity (sport practice) can be seen as a proxy for the preference for mobility, and also may be an indication of their health status.

Finally, we asked them the level of stress with respect to the COVID-19 risk at the time when the survey was implemented.

As the data shows in Table 1, 63 percent of the Korean students had a previous experience with online teaching, while French students did not. The fact that Korean student have a previous exposure to DE is not innocuous. Also, while French students followed only synchronous DE, Korean student were exposed to a mix of synchronous and asynchronous teaching. Therefore, any comparisons between the two samples should be performed with extreme caution.

The descriptive statistics by country are presented in Table 1.

French students are significantly more tolerant to risk. French students also report a higher collectivist attitude compared to Korean students, with an index of 0.56 for France, and 0.48 for Korea. In France B-Schools have a tradition of teaching and encouraging social values that might justify these figures. It turns out that for these categories, cultural differences might be much smaller than initially expected.

Korean students appear be have a higher score in the ability to fix computer problems and seem to spent more leisure time online prior to the burst of the epidemic.

The self-reported COVID-19 stress is much larger in Korea.

\footnotetext{
${ }^{6}$ A total of 162 students in Ile-de-France and 109 students in the Burgundy region participated in this survey.
} 
Table 1: Summary Statistics

\begin{tabular}{lcccccc}
\hline \hline & \multicolumn{2}{c}{$(1)$} & \multicolumn{2}{c}{$(2)$} & \multicolumn{2}{c}{$(3)$} \\
& \multicolumn{2}{c}{ France } & \multicolumn{2}{c}{ Korea } & \multicolumn{2}{c}{ ttest } \\
& mean & sd & mean & sd & b & se \\
\hline Age & 20.83 & 1.25 & 22.76 & 1.92 & $1.93^{* * *}$ & $(0.14)$ \\
Female & 0.59 & 0.49 & 0.44 & 0.50 & $-0.15^{* * *}$ & $(0.04)$ \\
Covid19 Stress & 0.48 & 0.29 & 0.63 & 0.25 & $0.15^{* * *}$ & $(0.02)$ \\
Online Before & 0.06 & 0.24 & 0.63 & 0.48 & $0.57^{* * *}$ & $(0.03)$ \\
Risk Tolerence & 0.68 & 0.19 & 0.42 & 0.23 & $-0.26^{* * *}$ & $(0.02)$ \\
Overconfidence & 0.32 & 0.34 & 0.35 & 0.42 & 0.03 & $(0.03)$ \\
Culture Orientation & 0.56 & 0.15 & 0.48 & 0.13 & $-0.08^{* * *}$ & $(0.01)$ \\
Computer Self-fix & 0.60 & 0.28 & 0.82 & 0.20 & $0.22^{* * *}$ & $(0.02)$ \\
Sport Practice & 0.60 & 0.28 & 0.64 & 0.27 & 0.03 & $(0.02)$ \\
Time-use Online & 0.75 & 0.18 & 0.82 & 0.17 & $0.07^{* * *}$ & $(0.02)$ \\
Time-use Game & 0.31 & 0.21 & 0.60 & 0.28 & $0.29^{* * *}$ & $(0.02)$ \\
\hline Observations & 271 & \multicolumn{10}{c}{239} & 510 & \\
\hline \hline
\end{tabular}

In Appendix Tables 1 and 2 we provide these statistics by country and by gender of the respondent. In both countries male subjects report better computer-fix skills and do more sports. The other gender differences are statistically weak: female students report a higher COVID-19 stress, are less risk tolerant, less overconfident and are less interested in gaming than male students in France; these gender differences are not statistically significant in Korea.

\section{Descriptive statistics}

Table 2 presents the key variables of our analysis.

1. "Satisfaction" is the index of self-reported global satisfaction with on-line teaching, normalized to one.

2. "Preference for online teaching" is an expression of revealed preference for online teaching, as the answer to the question "If you can choose between an online class an a similar in-class course available without any constraint, please state your preference for the in-class teaching". Answers from 0 (strong preference for in-class) to 5 (strong preference for on-line) were normalized to $[0,0.2,0.4,0.6,0.8,1]$.

3. "Effective time" is the self-reported proportion of time they effectively stay focused, in percent of total teaching time.

The overall satisfaction with online teaching turns out to be significantly higher in Korea compared to France. In both countries, a majority of students prefer in-class to on-line teaching; the balance against on-line teaching is extremely strong in France.

The proportion of effective time is much lower in France (51 per cent) compared to Korea (81 per cent). The French average score hides some variation in satisfaction scores between 
the two institutions where data were collected. No difference is observed with respect to the stated preference for online teaching (see Appendix Table A5).

Table 2: Summary Statistics

\begin{tabular}{|c|c|c|c|c|c|c|}
\hline & \multicolumn{2}{|c|}{ (1) } & \multicolumn{2}{|c|}{$\begin{array}{c}(2) \\
\text { Korea }\end{array}$} & \multicolumn{2}{|c|}{$\begin{array}{l}\text { (3) } \\
\text { ttest }\end{array}$} \\
\hline & mean & sd & mean & sd & $\mathrm{b}$ & se \\
\hline Satisfaction & 0.55 & 0.24 & 0.64 & 0.22 & $0.10^{* * *}$ & $(0.02)$ \\
\hline Preference Online & 0.15 & 0.24 & 0.40 & 0.29 & $0.25^{* * *}$ & $(0.02)$ \\
\hline Effective Time Spent & 0.51 & 0.25 & 0.81 & 0.21 & $0.30^{* * *}$ & $(0.02)$ \\
\hline Q1. Learning Process & 0.44 & 0.22 & 0.53 & 0.21 & $0.09^{* * *}$ & $(0.02)$ \\
\hline Q2. Volume & 0.48 & 0.23 & 0.58 & 0.20 & $0.10^{* * *}$ & $(0.02)$ \\
\hline Q3. Concept Transmission & 0.39 & 0.20 & 0.61 & 0.25 & $0.22^{* * *}$ & $(0.02)$ \\
\hline Q4. Interaction Students & 0.36 & 0.23 & 0.39 & 0.20 & 0.03 & $(0.02)$ \\
\hline Q5. Interaction Professor & 0.38 & 0.22 & 0.42 & 0.19 & $0.04^{*}$ & $(0.02)$ \\
\hline Q6. Social Interaction & 0.31 & 0.17 & 0.40 & 0.19 & $0.10^{* * *}$ & $(0.02)$ \\
\hline Q7. Losing Attention & 0.18 & 0.24 & 0.40 & 0.28 & $0.22^{* * *}$ & $(0.02)$ \\
\hline Observations & 271 & & 239 & & 510 & \\
\hline
\end{tabular}

The other variables in Table 2 are components of total satisfaction, which are answers to these items:

Q1. Compared to a face-to-face course, online courses brings you more/less satisfaction with respect to the learning process

Q2. Compared to a face-to-face course, the online course allows for the transmission of a smaller/larger volume of knowledge

Q3. Compared to a face-to-face course, the online course allows you to worse/better assimilate the concepts

Q4. Compared to a face-to-face course, the online course allows for poorer/richer courserelated interactions between students

Q5. Compared to a face-to-face course, the online course allows for poorer/richer courserelated interactions between a student and the professor

Q6. Compared to a face-to-face course, the online course makes it possible to socialize, or to create interactions between participants independent of the content of the course, more important

Q7. Compared to a face-to-face course, attention during a session decreases more/less quickly

Q8. Compared to the face-to-face course, the interactive online course requires less/more preparation on your part.

Items from 1 to 7 are positively and significantly correlated to the global satisfaction score. Q8 (preparation for the class) is not correlated, thus cannot be seen as a dimension of quality. The pairwise correlation matrix is presented in the Appendix Table A3. We also use Principal Component Analysis (PCA) to build an index of satisfaction using information contained in the 


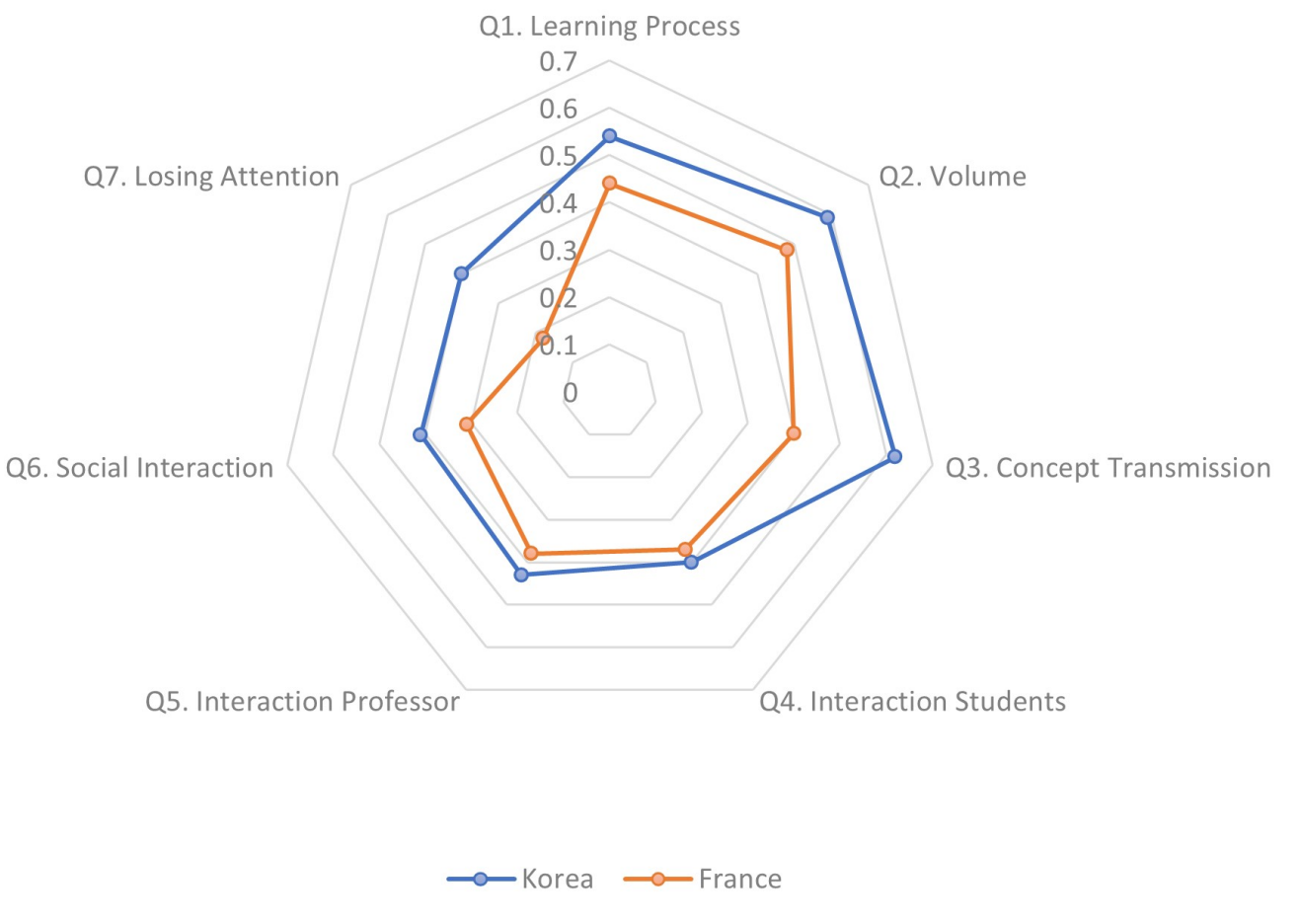

Figure 1: Components of Satisfaction with Online Teaching

seven items. This index is correlated with the global satisfaction index (corr. 0.602). Therefore we can use the global satisfaction index in the following analyses.

Figure 1 represents the size of the various dimensions of satisfaction (items 1 to 7 as defined before). French students are extremely negative with respect to Q3 (content assimilation) and Q7 (declining attention).

As already mentioned, overall Korean students report a higher satisfaction compared to French students (Figure 2).

In both countries the satisfaction level presents single-peak distributions, representative of significant variation among the respondents (Figure 3). This variation requires to develop a more precise analysis.

In both countries women express higher satisfaction with online teaching, and so do people with a high computer self-fix ability (knowing that male declare better ease with computers).

Figure 7 indicates the distribution the the answers to the "if you can choose between in class and online, what do you prefer" question ( 0 is strong preference for in-class teaching, 1 is strong preference for online teaching).

The graph reveals a very high density of the strong preference for in-class teaching in France, and a more homogeneous distribution in Korea.

Finally, Figure 8 indicates the distribution of the effective time. Many Korean students report full intensity. This can possibly be explained by the fact that a substantial part of the DE is based 


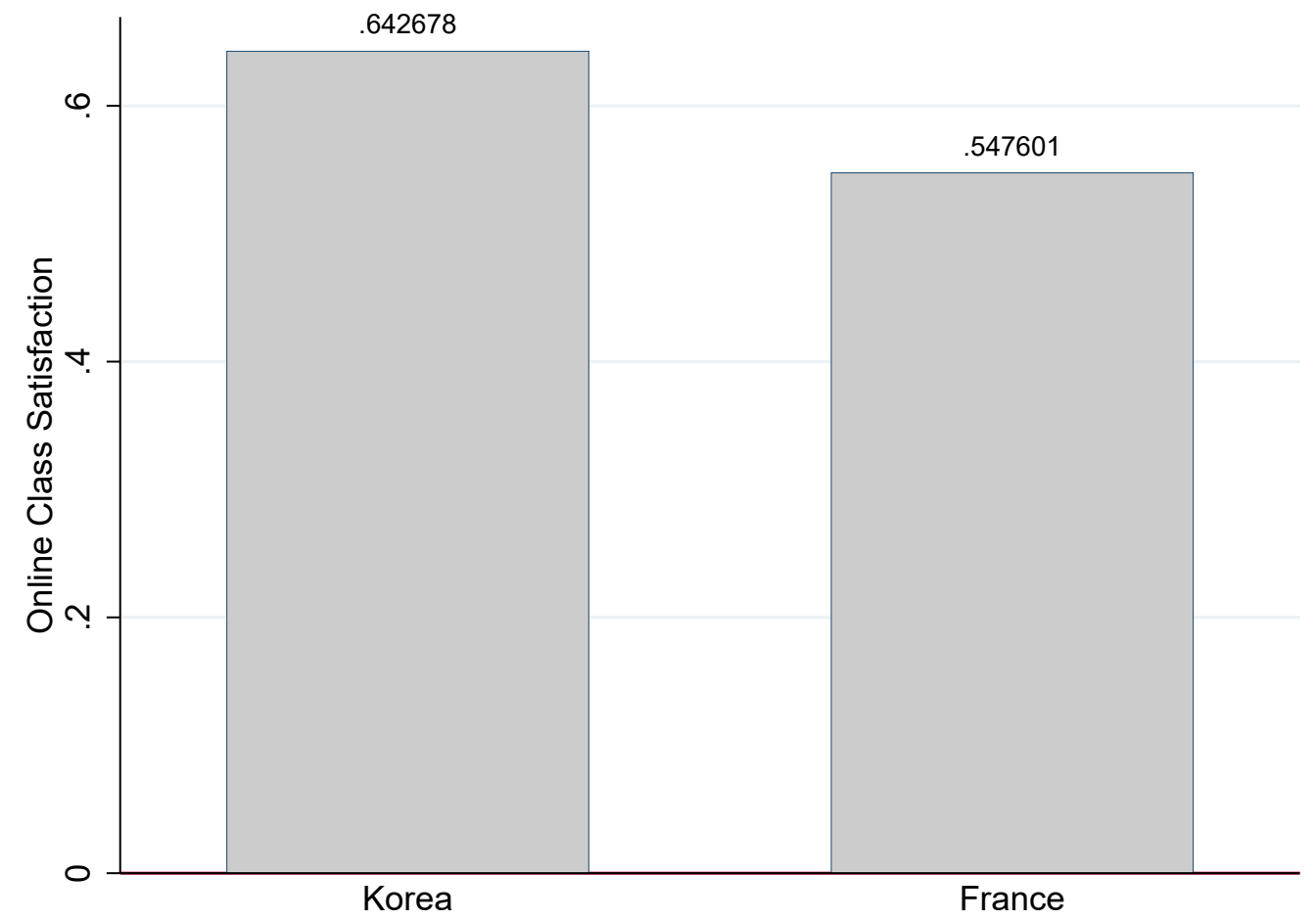

Figure 2: Satisfaction with online teaching (mean value by country) 


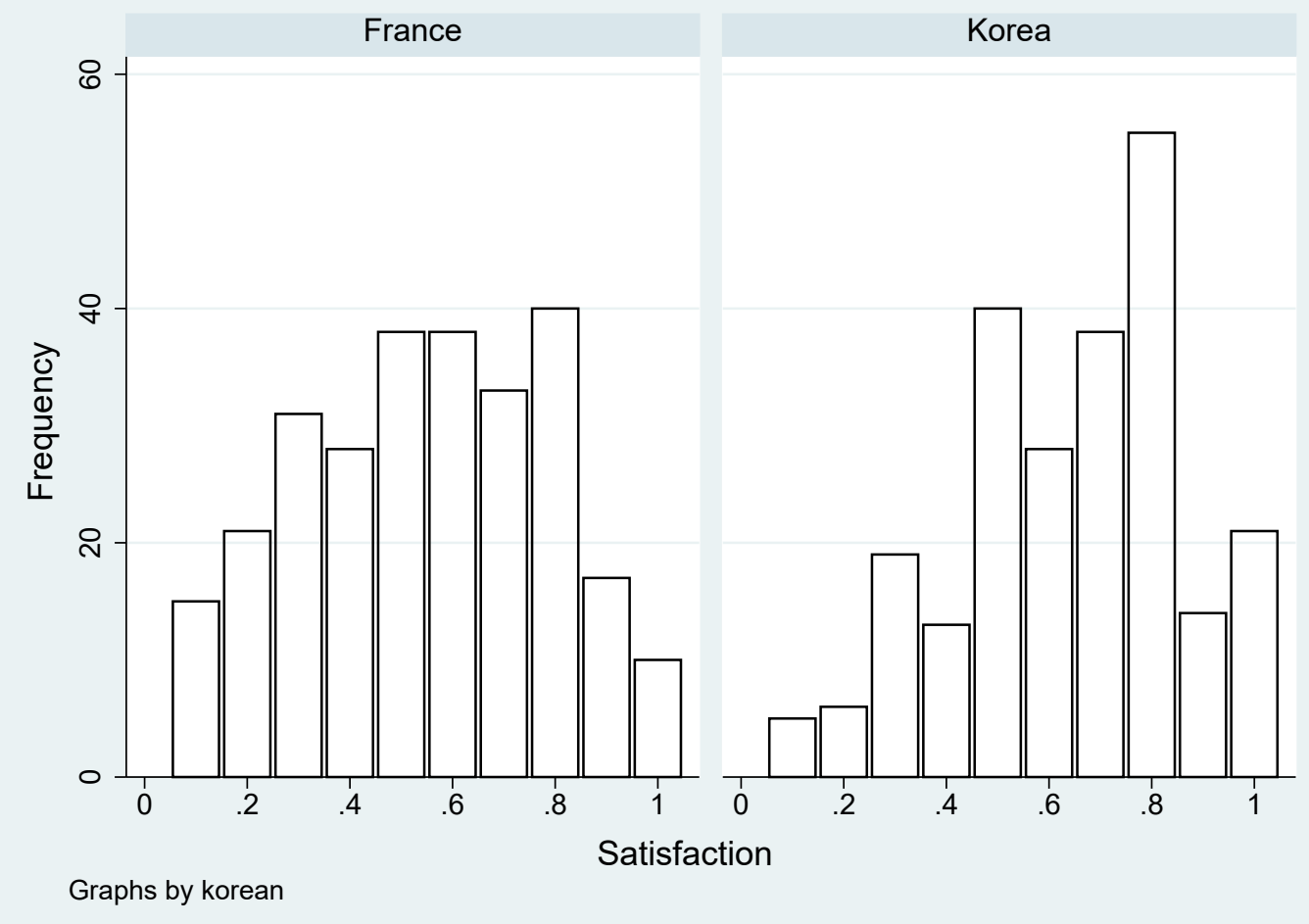

Figure 3: Satisfaction Distribution 

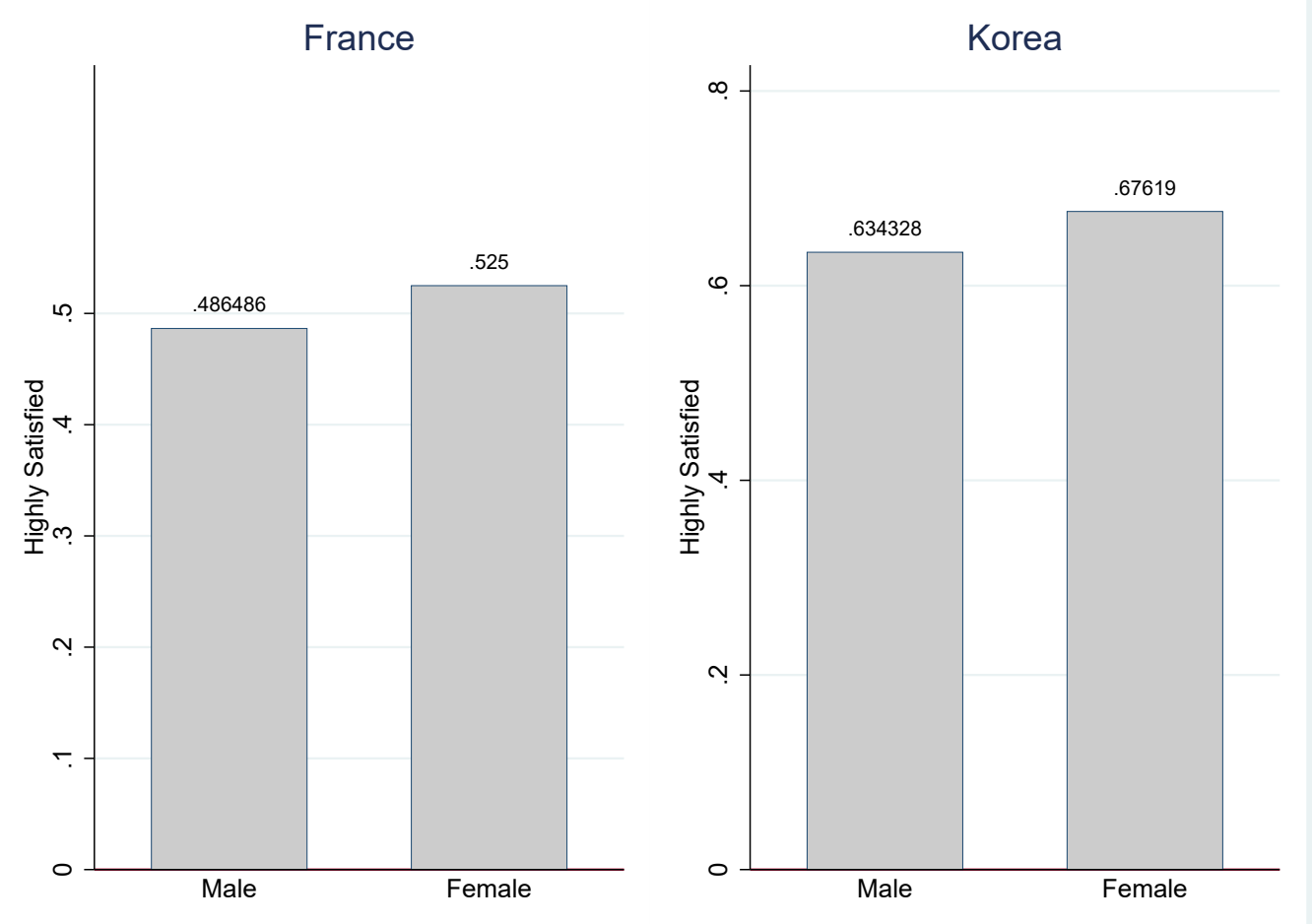

Figure 4: Satisfaction with online teaching by gender (Highly Satisfied $=1$ ) 

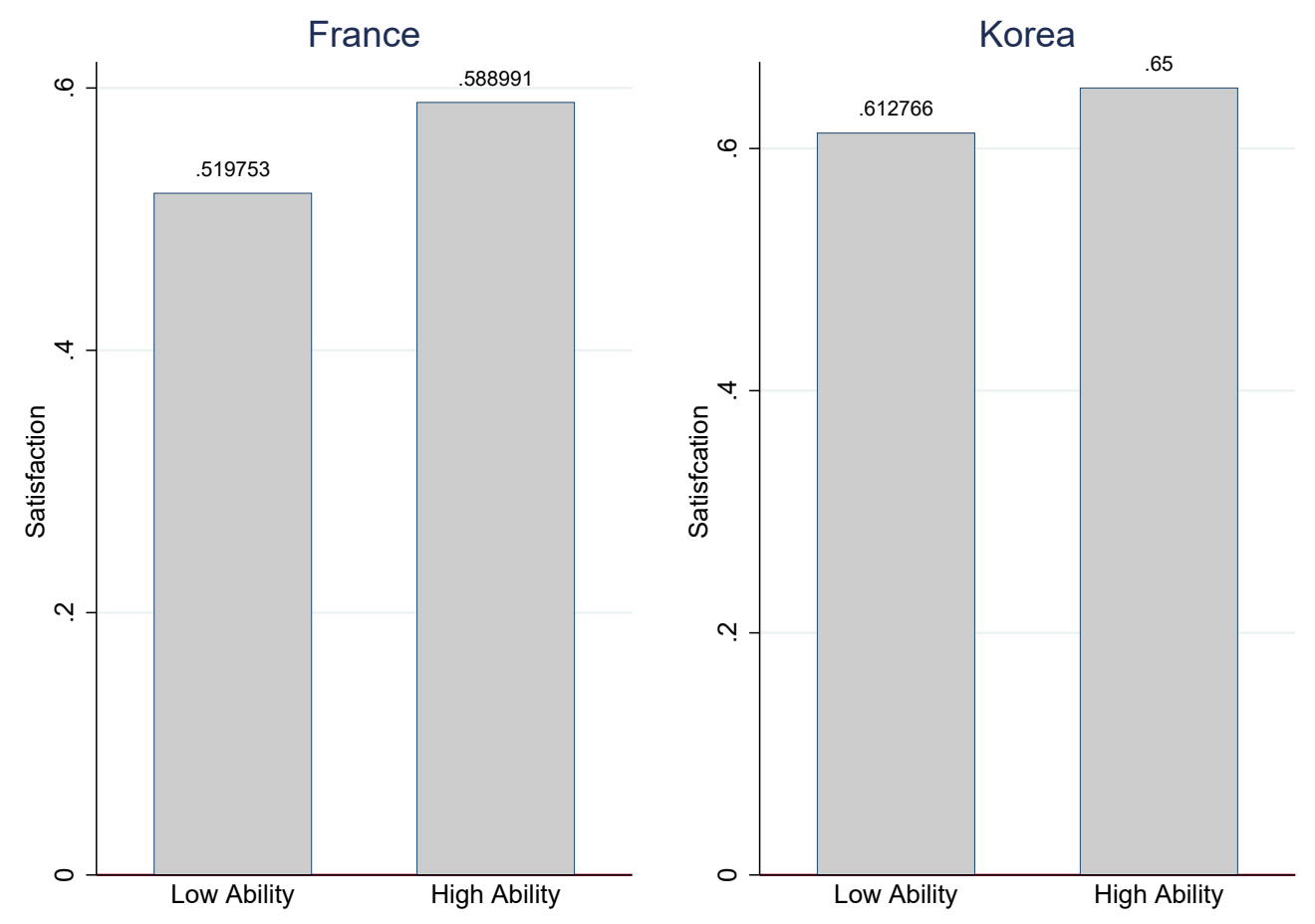

Figure 5: Satisfaction by Computer Self-fix Ability 


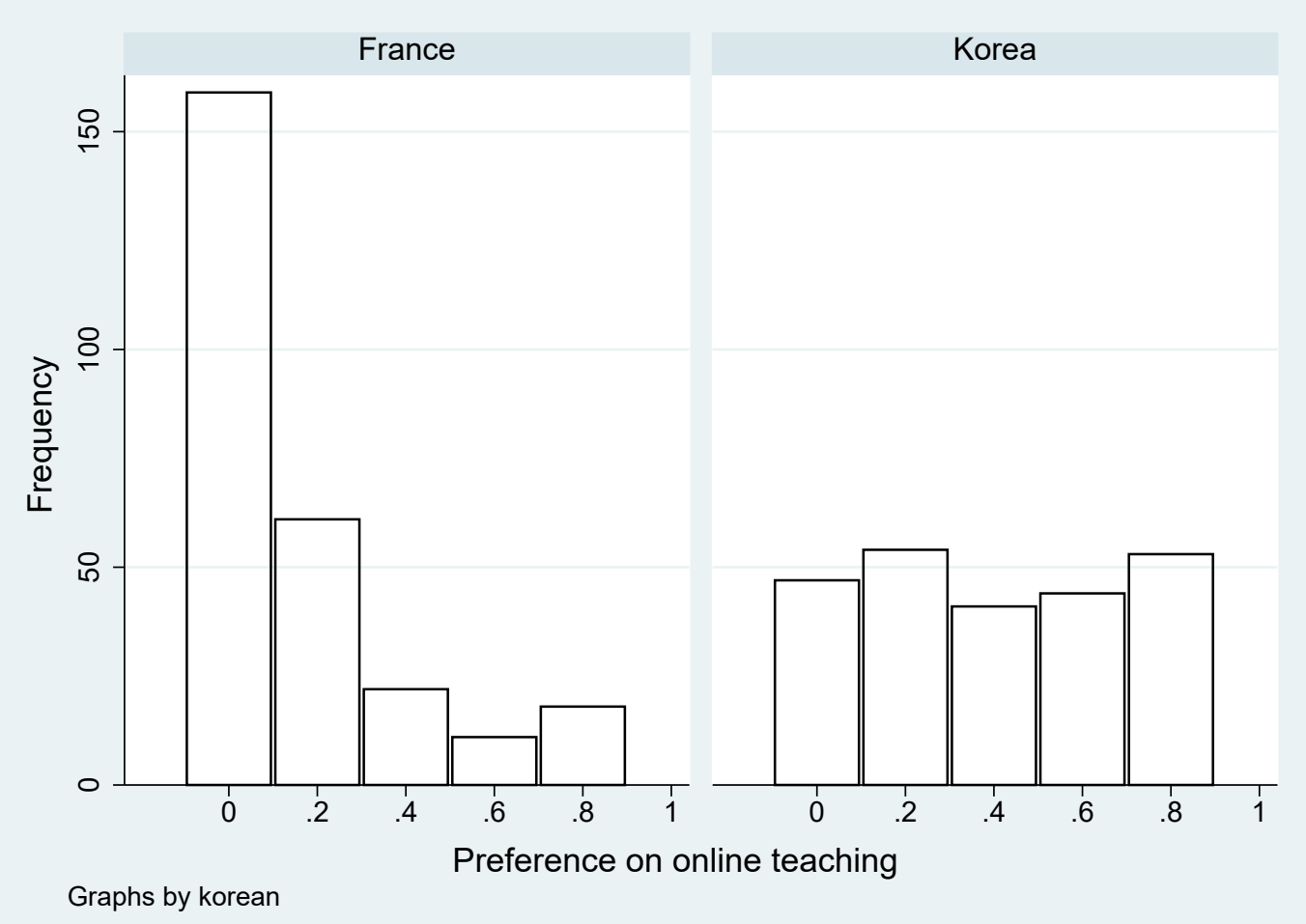

Figure 6: Distribution of Stated Preferences for Online Teaching 


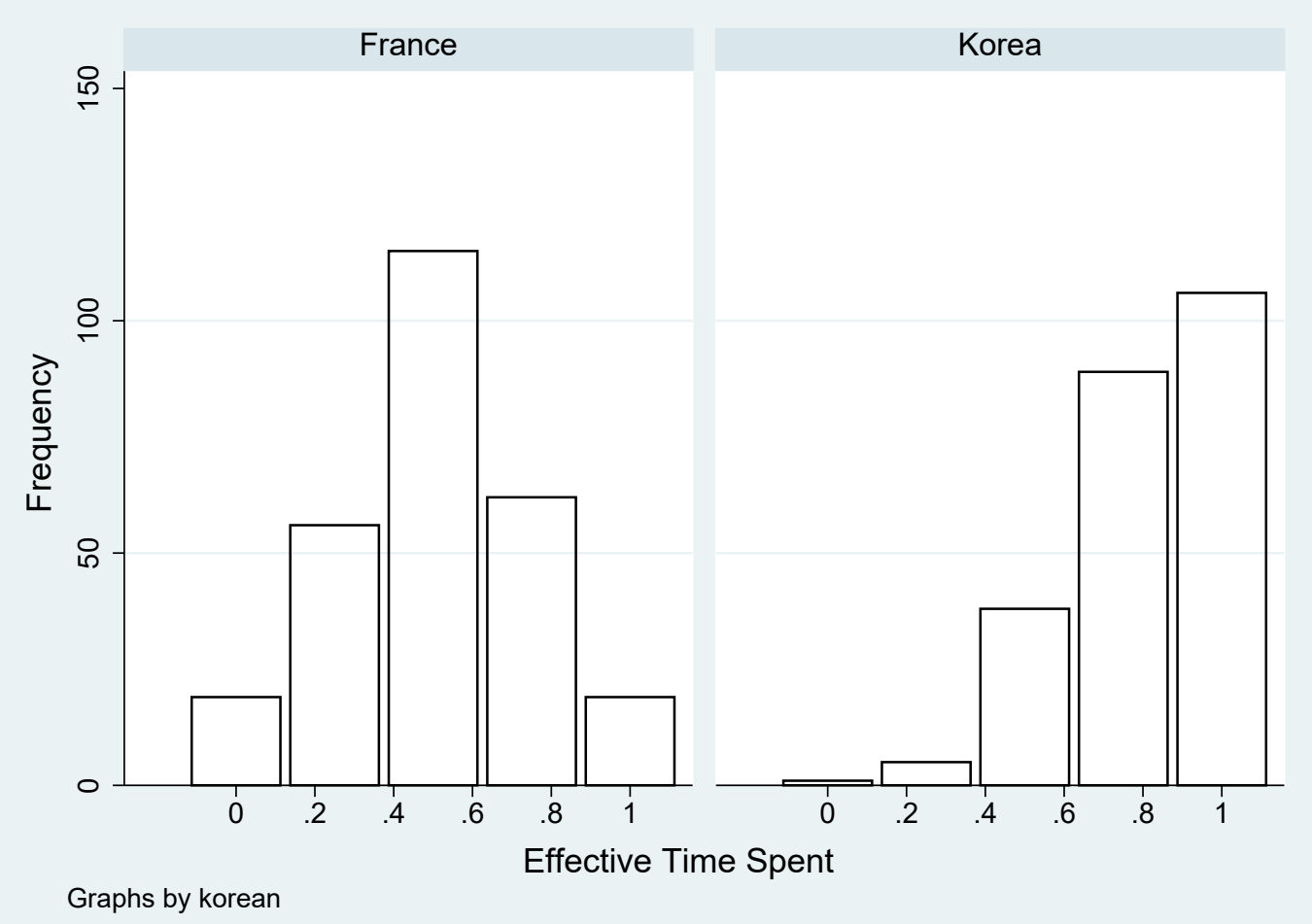

Figure 7: Distribution of Effective Online Time

on asynchronous education (recorded videos).

\section{Regression analysis}

Regression analysis allows us to move beyond these descriptive statistics. Tables 3 and 4 present results from OLS regression models, separately for France and Korea, and for the full sample, using as dependent variables "Satisfaction with online" , and the "Preference for online (against in-class) teaching" as previously defined. Because data for France come from two different institutions, errors are clustered by institutions.

As we can see, in both countries women express a higher satisfaction with online teaching.

The relationship between COVID-19 stress and satisfaction with online teaching can go either ways. On the one hand, online teaching is increasing physical distance, and reduces the risk of contamination. On the other hand, a higher COVID-19 stress can have a negative effect on satisfaction with education in general, because of the negative emotions it can generate. In Korea the correlation is negative - the latter effect is stronger, but not in France, where the positive (social distance) effects seems to take over the former. A similar result is obtained in Table 4 (in France the two effect just cancel each other).

An important factor of satisfaction for the Korean sample is the ability to fix simple computer breakdowns, which depends on their experience, previous training and IT talent. In the all-data 
Table 3: Satisfaction

\begin{tabular}{|c|c|c|c|}
\hline & $\begin{array}{l}(1) \\
\text { France }\end{array}$ & $\begin{array}{c}(2) \\
\text { Korea }\end{array}$ & $\begin{array}{l}\text { (3) } \\
\text { All }\end{array}$ \\
\hline Covid19 Stress & $\begin{array}{l}0.0973 * * \\
(0.00234)\end{array}$ & $\begin{array}{l}-0.174 * * * * \\
(0.0575)\end{array}$ & $\begin{array}{l}-0.173 * * * x \\
(0.00276)\end{array}$ \\
\hline Female & $\begin{array}{l}0.0792^{* *} \\
(0.00128)\end{array}$ & $\begin{array}{l}0.0782^{* *} \\
(0.0334)\end{array}$ & $\begin{array}{l}0.0791 * * \\
(0.00801)\end{array}$ \\
\hline Online Before & $\begin{array}{c}0.0675 \\
(0.0862)\end{array}$ & $\begin{array}{l}-0.0722^{* *} \\
(0.0298)\end{array}$ & $\begin{array}{l}-0.0431 \\
(0.0395)\end{array}$ \\
\hline Age & $\begin{array}{l}0.00698 \\
(0.0177)\end{array}$ & $\begin{array}{c}0.00271 \\
(0.00827)\end{array}$ & $\begin{array}{c}0.00483 \\
(0.00423)\end{array}$ \\
\hline Overconfidence & $\begin{array}{c}0.118 * \cdots * \\
(0.000157)\end{array}$ & $\begin{array}{c}0.0486 \\
(0.0356)\end{array}$ & $\begin{array}{l}0.0428 * * \\
(0.00716)\end{array}$ \\
\hline Culture Orientation & $\begin{array}{l}-0.0672 \\
(0.160)\end{array}$ & $\begin{array}{l}0.201 * \\
(0.113)\end{array}$ & $\begin{array}{l}0.192 * * * \\
(0.0167)\end{array}$ \\
\hline Risk Tolerence & $\begin{array}{l}-0.0548 \\
(0.133)\end{array}$ & $\begin{array}{l}-0.0119 \\
(0.0645)\end{array}$ & $\begin{array}{l}-0.0116 * * \\
(0.00199)\end{array}$ \\
\hline Time-use Online & $\begin{array}{c}0.212 \\
(0.229)\end{array}$ & $\begin{array}{l}-0.0429 \\
(0.0894)\end{array}$ & $\begin{array}{l}-0.0487 * * \\
(0.00838)\end{array}$ \\
\hline Time-use Game & $\begin{array}{c}0.111 \\
(0.0460)\end{array}$ & $\begin{array}{c}0.0696 \\
(0.0539)\end{array}$ & $\begin{array}{l}0.0720 * \cdots \\
(0.00267)\end{array}$ \\
\hline Computer Self-fix & $\begin{array}{c}0.165 \\
(0.0926)\end{array}$ & $\begin{array}{l}0.171 * * \\
(0.0741)\end{array}$ & $\begin{array}{l}0.175 * * * * \\
(0.00601)\end{array}$ \\
\hline Sport Practice & $\begin{array}{l}0.0840 * * \\
(0.00560)\end{array}$ & $\begin{array}{c}0.0761 \\
(0.0534)\end{array}$ & $\begin{array}{l}0.0722^{* * *} \\
(0.00447)\end{array}$ \\
\hline France & & & $\begin{array}{l}-0.295 \\
(0.209)\end{array}$ \\
\hline France $\times$ Covid19 Stress & & & $\begin{array}{l}0.0270 * * * \\
(0.00157)\end{array}$ \\
\hline France $\times$ Female & & & $\begin{array}{l}-0.00164 \\
(0.00997)\end{array}$ \\
\hline France $\times$ Overconfidence & & & $\begin{array}{l}0.0878^{* *} \\
(0.0104)\end{array}$ \\
\hline France $\times$ Culture Orientation & & & $\begin{array}{l}-0.264 \\
(0.161)\end{array}$ \\
\hline France $\times$ Risk Tolerence & & & $\begin{array}{l}-0.0224 \\
(0.123)\end{array}$ \\
\hline France $\times$ Time-use Online & & & $\begin{array}{c}0.0431 \\
(0.0320)\end{array}$ \\
\hline France $\times$ Time-use Game & & & $\begin{array}{c}0.00824 \\
(0.00395)\end{array}$ \\
\hline France $\times$ Compueter Self-fix & & & $\begin{array}{c}-0.0194 \\
(0.0892)\end{array}$ \\
\hline France $\times$ Sport Practice & & & $\begin{array}{l}0.000200 \\
(0.00124)\end{array}$ \\
\hline Constant & $\begin{array}{c}-0.00212 \\
(0.122)\end{array}$ & $\begin{array}{l}0.399 * \\
(0.228)\end{array}$ & $\begin{array}{l}0.339^{*} \\
(0.102)\end{array}$ \\
\hline $\begin{array}{l}\text { Observations } \\
\text { Adjusted } R^{2}\end{array}$ & $\begin{array}{c}271 \\
0.092\end{array}$ & $\begin{array}{c}239 \\
0.065\end{array}$ & $\begin{array}{c}510 \\
0.111\end{array}$ \\
\hline
\end{tabular}

Significant level: * $0.1 * * 0.05 * * * 0.01$

Standard Errors are clustered by institutions 
Table 4: Online Preference

\begin{tabular}{|c|c|c|c|}
\hline & $\begin{array}{l}(1) \\
\text { France }\end{array}$ & $\begin{array}{c}(2) \\
\text { Korea }\end{array}$ & $\begin{array}{l}\text { (3) } \\
\text { All }\end{array}$ \\
\hline Covid19 Stress & $\begin{array}{c}0.000254 \\
(0.000795)\end{array}$ & $\begin{array}{c}-0.286 * * * \\
(0.0759)\end{array}$ & $\begin{array}{l}-0.287 * * * \\
(0.00135)\end{array}$ \\
\hline Female & $\begin{array}{c}-0.0183 \\
(0.0630)\end{array}$ & $\begin{array}{l}0.0754 * \\
(0.0441)\end{array}$ & $\begin{array}{l}0.0835 * * * \\
(0.00782)\end{array}$ \\
\hline Online Before & $\begin{array}{l}-0.0439 \\
(0.0677)\end{array}$ & $\begin{array}{l}-0.0281 \\
(0.0393)\end{array}$ & $\begin{array}{l}-0.0319 \\
(0.0140)\end{array}$ \\
\hline Age & $\begin{array}{c}0.0180 * * * * \\
(0.0000708)\end{array}$ & $\begin{array}{l}0.00562 \\
(0.0109)\end{array}$ & $\begin{array}{c}0.0102 \\
(0.00450)\end{array}$ \\
\hline Overconfidence & $\begin{array}{c}0.0358 \\
(0.0540)\end{array}$ & $\begin{array}{l}-0.00518 \\
(0.0471)\end{array}$ & $\begin{array}{c}-0.00582 \\
(0.00269)\end{array}$ \\
\hline Culture Orientation & $\begin{array}{l}-0.337 \\
(0.124)\end{array}$ & $\begin{array}{l}-0.192 \\
(0.149)\end{array}$ & $\begin{array}{l}-0.184 * * * * \\
(0.00880)\end{array}$ \\
\hline Risk Tolerence & $\begin{array}{l}0.0217 \\
(0.141)\end{array}$ & $\begin{array}{l}-0.0452 \\
(0.0852)\end{array}$ & $\begin{array}{c}-0.0431^{* * * *} \\
(0.00199)\end{array}$ \\
\hline Time-use Online & $\begin{array}{c}-0.000470 \\
(0.0862)\end{array}$ & $\begin{array}{l}-0.227^{*} \\
(0.118)\end{array}$ & $\begin{array}{l}-0.226 \\
(0.00317)\end{array}$ \\
\hline Time-use Game & $\begin{array}{c}0.175 \\
(0.0987)\end{array}$ & $\begin{array}{c}0.0428 \\
(0.0713)\end{array}$ & $\begin{array}{l}0.0440 \\
(0.00150)\end{array}$ \\
\hline Computer Self-fix & $\begin{array}{l}-0.0377 \\
(0.0741)\end{array}$ & $\begin{array}{c}0.0856 \\
(0.0979)\end{array}$ & $\begin{array}{l}0.0851^{* \cdots *} \\
(0.00212)\end{array}$ \\
\hline Sport Practice & $\begin{array}{c}0.0657 \\
(0.0741)\end{array}$ & $\begin{array}{c}0.0518 \\
(0.0705)\end{array}$ & $\begin{array}{l}0.0490 * * * \\
(0.00320)\end{array}$ \\
\hline France & & & $\begin{array}{l}-0.461 * * \\
(0.0943)\end{array}$ \\
\hline France $\times$ Covid19 Stress & & & $\begin{array}{c}0.0292 * * * \\
(0.000278)\end{array}$ \\
\hline France $\times$ Female & & & $\begin{array}{c}-0.101 \\
(0.0531)\end{array}$ \\
\hline France $\times$ Overconfidence & & & $\begin{array}{c}0.0429 \\
(0.0556)\end{array}$ \\
\hline France $\times$ Culture Orientation & & & $\begin{array}{l}-0.158 \\
(0.108)\end{array}$ \\
\hline France $\times$ Risk Tolerence & & & $\begin{array}{l}0.0662 \\
(0.128)\end{array}$ \\
\hline France $\times$ Time-use Online & & & $\begin{array}{l}0.0385^{*} \\
(0.0132)\end{array}$ \\
\hline France $\times$ Time-use Game & & & $\begin{array}{c}0.0213 \\
(0.0146)\end{array}$ \\
\hline France $\times$ Compueter Self-fix & & & $\begin{array}{c}-0.119 \\
(0.0691)\end{array}$ \\
\hline France $\times$ Sport Practice & & & $\begin{array}{c}0.00164 \\
(0.00661)\end{array}$ \\
\hline Constant & $\begin{array}{c}-0.117 \\
(0.126)\end{array}$ & $\begin{array}{l}0.609^{* *} \\
(0.301)\end{array}$ & $\begin{array}{l}0.501 * * \\
(0.108)\end{array}$ \\
\hline Observations & 271 & 239 & 510 \\
\hline Adjusted $R^{2}$ & 0.047 & 0.049 & 0.222 \\
\hline
\end{tabular}


equation, IT skills are positively related to satisfaction.

It is difficult to interpret the coefficient of the cultural orientation. In the preference for online teaching, the sign is negative. This is aligned with intuitive reasoning, with less individualistic subjects being more averse to online teaching. However, the sign is positive in the all-sample satisfaction model, which is somehow puzzling.

Gamers who use to spent time before the computer screens, express higher satisfaction with online teaching (in the overall sample).

The practice of sport is positively related to satisfaction in the overall sample.

Table A4 in the Appendix presents similar regression models, using as a dependent variable the effective time spend on line, and reveal, mostly similar results.

These results suggest that satisfaction with online teaching is to some extent difficult to

explain by elementary traits of personality, and furthermore, can significantly differ from one country to another.

\section{Concluding Remarks}

The outbreak of the COVID-19 pandemic imposed on many governments the hard choice of closing schools and higher education institutions. Synchronous and Interactive Online Education (SIOE) became, at short notice, the main solution for maintaining the continuity of the education process, seconded by asynchronous DE methods (MOOCs, recorded videos).

This paper reports the results from a survey on student satisfaction with on-line teaching as implemented in France and Korea in May 2020. At that time France was imposing a ban on all non-essential activities and restricted the mobility of persons by administrative authorizations. In Korea the sanitary situation was under control with a reduced number of case fatalities; however, in Korea too higher education institutions were using only distance education.

The results show that while DE is seen by respondents as a workable solution in an emergency situation, for many students it is not the preferred solution compared to traditional, in-class teaching. In particular, students exposed to SIOE are critical with respect to the limited social interactions, and the difficulty in maintaining attention focused.

French students are more critical than Korean students with respect to all dimensions of satisfaction. In both countries women appear to have a more favourable appreciation toward online teaching, compared to men.

The COVID-19 stress has two opposite effects on satisfaction. In general, it will generate negative emotions (anxiety, sadness, etc.) that bring about a negative effect on satisfaction in general. On the other hand, DE is limiting the risk of contagion, which should have a positive effect on satisfaction. In Korea the COVID-19 related stress is negatively associated to satisfaction with online classes, representative of a stronger first effect. In France, the association between the COVID-19 stress and satisfaction is positive, indicative of a stronger second effect.

For sure, results from such a small sample survey, on a non-representative sample of students, should be interpreted with extreme caution. Despite these important limitations, these answers reveal that the satisfaction with education depends on many subtle and sometimes hidden factors, going well beyond the plain transmission of knowledge. Students exposed to 
DE miss the group interaction and the specific emotions generated by a in-the-classroom education experience. The quality of computer communication is often harmed by the speed of Internet which adds small transmission lags and entails a poor quality of sound and image. In turn, these psychological and technical limitations adversely affect student capacity to stay focused, to assimilate concepts, and ultimately harm their satisfaction with the education process. 


\section{References}

Allen, M., J. Bourhis, N. Burrell, and E. Mabry (2002). Comparing student satisfaction with distance education to traditional classrooms in higher education: A meta-analysis. The American Journal of Distance Education 16(2), 83-97.

Beeching, N., T. Fletcher, and E. Fowler (2020). Coronavirus disease 2019 (covid-19). A BMJ Report.

Dohmen, T., A. Falk, D. Huffman, and U. Sunde (2010, June). Are risk aversion and impatience related to cognitive ability? American Economic Review 100(3), 1238-60.

Dohmen, T., A. Falk, D. Huffman, U. Sunde, J. Schupp, and G. G. Wagner (2011). Individual risk attitudes: Measurement, determinants, and behavioral consequences. Journal of the European Economic Association 9(3), 522-550.

Fidalgo, P., J. Thormann, O. Kulyk, and J. A. Lencastre (2020). Students' perceptions on distance education: A multinational study. International Journal of Educational Technology in Higher Education 17, 1-18.

Fosslien, L. and M. W. Duffy (2020). How to combat zoom fatigue. Harvard Business Review.

Garrison, D. R. (2000). Theoretical challenges for distance education in the 21st century: A shift from structural to transactional issues. The International Review of Research in Open and Distance Learning 1(1), 1-17.

Goodyear, P., G. Salmon, J. M. Spector, C. Steeples, and S. Tickner (2001). Competences for online teaching: A special report. Educational Technology Research and Development 49(1), $65-72$.

Hofstede, G. (2001). Culture's Consequences: Comparing Values, Behaviors, Institutions, and Organizations Across Nations. Second Edition, Thousand Oaks CA: Sage Publications.

Jung, S. and R. Vranceanu (2019). Competitive compensation and subjective well-being: The effect of culture and gender. Journal of Economic Psychology 70, 90-108.

Keegan, D. (2002). The future of learning: From elearning to mlearning. Hagen: Zentrales Institut fur Fern Universitat.

Palloff, R. M. and K. Pratt (2013). Lessons from the virtual classroom: The realities of online teaching. John Wiley and Sons.

Summers, J., W. Waigandt, and T. Whittaker (2005). A comparison of student achievement and satisfaction in an online versus a traditional face-to-face statistics class. Innovative Higher Education 29(3), 233-250. 
Triandis, H. and M. Gelfland (1998). Individualism and collectivism scale (also known as the culture orientation scale). Journal of Personality and Social Psychology 74, 118-128.

Weerasinghe, I. S. and R. L. S. Fernando (2017). Students' satisfaction in higher education literature review. American Journal of Educational Research 5(5), 533-539.

Wei, H.-C. and C. Chou (2020). Online learning performance and satisfaction: do perceptions and readiness matter? Distance Education 41(1), 48-69. 


\section{A Appendix Tables}

Table A1: Summary Statistics: France

\begin{tabular}{lcccccc}
\hline \hline & \multicolumn{2}{c}{$(1)$} & \multicolumn{2}{c}{$(2)$} & \multicolumn{2}{c}{$(3)$} \\
& \multicolumn{2}{c}{ Female } & \multicolumn{2}{c}{ Male } & \multicolumn{2}{c}{ ttest } \\
& mean & sd & mean & sd & b & se \\
\hline Age & 20.84 & 1.16 & 20.81 & 1.38 & -0.03 & $(0.16)$ \\
Covid19 Stress & 0.54 & 0.28 & 0.40 & 0.27 & $-0.14^{* * *}$ & $(0.03)$ \\
Online Before & 0.04 & 0.21 & 0.08 & 0.27 & 0.04 & $(0.03)$ \\
Risk Tolerence & 0.66 & 0.19 & 0.72 & 0.19 & $0.06^{*}$ & $(0.02)$ \\
Overconfidence & 0.28 & 0.32 & 0.38 & 0.36 & $0.11^{* *}$ & $(0.04)$ \\
Culture Orientation & 0.56 & 0.15 & 0.56 & 0.15 & -0.00 & $(0.02)$ \\
Computer Self-fix & 0.55 & 0.26 & 0.68 & 0.28 & $0.13^{* * *}$ & $(0.03)$ \\
Sport Practice & 0.57 & 0.28 & 0.64 & 0.28 & $0.07^{*}$ & $(0.03)$ \\
Time-use Online & 0.75 & 0.17 & 0.77 & 0.19 & 0.02 & $(0.02)$ \\
Time-use Game & 0.25 & 0.17 & 0.40 & 0.23 & $0.16^{* * *}$ & $(0.02)$ \\
\hline Observations & 160 & & 111 & & 271 & \\
\hline \hline
\end{tabular}


Table A2: Summary Statistics: Korea

\begin{tabular}{lcccccc}
\hline \hline & \multicolumn{2}{c}{$(1)$} & \multicolumn{2}{c}{$(2)$} & \multicolumn{2}{c}{$(3)$} \\
& $\begin{array}{c}\text { Female } \\
\text { mean }\end{array}$ & sd & mean & sd & b & se \\
\hline Age & 21.80 & 1.33 & 23.51 & 1.98 & $1.71^{* * *}$ & $(0.22)$ \\
Covid19 Stress & 0.66 & 0.23 & 0.61 & 0.26 & -0.05 & $(0.03)$ \\
Online Before & 0.69 & 0.47 & 0.59 & 0.49 & -0.10 & $(0.06)$ \\
Risk Tolerence & 0.38 & 0.22 & 0.44 & 0.24 & 0.06 & $(0.03)$ \\
Overconfidence & 0.32 & 0.41 & 0.38 & 0.44 & 0.06 & $(0.06)$ \\
Culture Orientation & 0.48 & 0.13 & 0.48 & 0.13 & 0.00 & $(0.02)$ \\
Computer Self-fix & 0.79 & 0.21 & 0.85 & 0.18 & $0.06^{*}$ & $(0.03)$ \\
Sport Practice & 0.58 & 0.28 & 0.68 & 0.26 & $0.09^{* *}$ & $(0.04)$ \\
Time-use Online & 0.86 & 0.13 & 0.79 & 0.19 & $-0.07^{* *}$ & $(0.02)$ \\
Time-use Game & 0.57 & 0.30 & 0.62 & 0.26 & 0.05 & $(0.04)$ \\
\hline Observations & 105 & \multicolumn{13}{c}{134} & \multicolumn{4}{c}{239} & \\
\hline \hline
\end{tabular}

Table A3: Pairwise Correlation

\begin{tabular}{lc}
\hline \hline & $(1)$ \\
& sat \\
\hline Satisfaction PCA & $0.602^{* * *}$ \\
Satisfaction compared to Initial Expectation & $0.740^{* * *}$ \\
Preference Online & $0.481^{* * *}$ \\
Q1. Learning Process & $0.531^{* * *}$ \\
Q2. Volume & $0.476^{* * *}$ \\
Q3. Concept Transmission & $0.559^{* * *}$ \\
Q4. Interaction Students & $0.258^{* * *}$ \\
Q5. Interaction Professor & $0.350^{* * *}$ \\
Q6. Social Interaction & $0.319^{* * *}$ \\
Q7. Losing Attention & $0.438^{* * *}$ \\
\hline Observations & 510 \\
\hline \hline${ }^{*} p<0.05,{ }^{* *} p<0.01,{ }^{* * *} p<0.001$ &
\end{tabular}


Table A4: Effective Time spent

\begin{tabular}{|c|c|c|c|}
\hline & $\begin{array}{l}(1) \\
\text { France }\end{array}$ & $\begin{array}{c}(2) \\
\text { Korea }\end{array}$ & $\begin{array}{l}\text { (3) } \\
\text { All }\end{array}$ \\
\hline Covid19 Stress & $\begin{array}{c}0.195^{*} \\
(0.0221)\end{array}$ & $\begin{array}{l}0.00682 \\
(0.0549)\end{array}$ & $\begin{array}{l}0.00801 * \\
(0.00250)\end{array}$ \\
\hline Female & $\begin{array}{c}0.0369 * \\
(0.00298)\end{array}$ & $\begin{array}{l}0.00487 \\
(0.0319)\end{array}$ & $\begin{array}{l}-0.00464 \\
(0.0170)\end{array}$ \\
\hline Online Before & $\begin{array}{l}-0.0457 \\
(0.0592)\end{array}$ & $\begin{array}{l}-0.0506 * \\
(0.0284)\end{array}$ & $\begin{array}{l}-0.0491 * * \\
(0.0102)\end{array}$ \\
\hline Age & $\begin{array}{l}-0.0149 \\
(0.0222)\end{array}$ & $\begin{array}{l}0.0000338 \\
(0.00789)\end{array}$ & $\begin{array}{l}-0.00554 \\
(0.00960)\end{array}$ \\
\hline Overconfidence & $\begin{array}{c}0.0714 \\
(0.0367)\end{array}$ & $\begin{array}{c}0.0400 \\
(0.0340)\end{array}$ & $\begin{array}{l}0.0413 * * * \\
(0.00135)\end{array}$ \\
\hline Culture Orientation & $\begin{array}{l}-0.193 \\
(0.187)\end{array}$ & $\begin{array}{l}-0.0670 \\
(0.107)\end{array}$ & $\begin{array}{c}-0.0753 * * \\
(0.0170)\end{array}$ \\
\hline Risk Tolerence & $\begin{array}{l}-0.0740 \\
(0.0641)\end{array}$ & $\begin{array}{c}-0.0498 \\
(0.0615)\end{array}$ & $\begin{array}{l}-0.0523 * * * * \\
(0.00431)\end{array}$ \\
\hline Time-use Online & $\begin{array}{l}0.0817 \\
(0.382)\end{array}$ & $\begin{array}{c}0.0517 \\
(0.0854)\end{array}$ & $\begin{array}{l}0.0503^{* \cdots *} \\
(0.00384)\end{array}$ \\
\hline Time-use Game & $\begin{array}{c}0.00287 \\
(0.00443)\end{array}$ & $\begin{array}{l}-0.0659 \\
(0.0515)\end{array}$ & $\begin{array}{l}-0.0674 \div * * * \\
(0.00231)\end{array}$ \\
\hline Computer Self-fix & $\begin{array}{c}0.230^{*} \\
(0.0218)\end{array}$ & $\begin{array}{l}-0.103 * \\
(0.0708)\end{array}$ & $\begin{array}{l}-0.103 * * * \\
(0.00128)\end{array}$ \\
\hline Sport Practice & $\begin{array}{c}0.0120 \\
(0.00462)\end{array}$ & $\begin{array}{l}0.119 * * \\
(0.0510)\end{array}$ & $\begin{array}{l}0.123 * \div * \\
(0.00582)\end{array}$ \\
\hline France & & & $\begin{array}{l}-0.567 \\
(0.371)\end{array}$ \\
\hline France $\times$ Covid19 Stress & & & $\begin{array}{l}0.0181 * * \\
(0.00286)\end{array}$ \\
\hline France $\times$ Female & & & $\begin{array}{l}0.0412^{*} \\
(0.0149)\end{array}$ \\
\hline France $\times$ Overconfidence & & & $\begin{array}{c}0.0274 \\
(0.0297)\end{array}$ \\
\hline France $\times$ Culture Orientation & & & $\begin{array}{l}-0.111 \\
(0.186)\end{array}$ \\
\hline France $\times$ Risk Tolerence & & & $\begin{array}{c}-0.0254 \\
(0.0634)\end{array}$ \\
\hline France $\times$ Time-use Online & & & $\begin{array}{l}0.00412 \\
(0.0552)\end{array}$ \\
\hline France $\times$ Time-use Game & & & $\begin{array}{l}0.0121 \ldots * \cdots \\
(0.000920)\end{array}$ \\
\hline France $\times$ Compueter Self-fix & & & $\begin{array}{l}0.329 \div \div * \\
(0.00774)\end{array}$ \\
\hline France $\times$ Sport Practice & & & $\begin{array}{c}-0.0110 * * * \\
(0.00103)\end{array}$ \\
\hline Constant & $\begin{array}{c}0.631 * \\
(0.0586)\end{array}$ & $\begin{array}{c}0.877^{* * * *} \\
(0.218)\end{array}$ & $\begin{array}{l}1.010^{* * *} \\
(0.228)\end{array}$ \\
\hline $\begin{array}{l}\text { Observations } \\
\text { Adjusted } R^{2}\end{array}$ & $\begin{array}{c}271 \\
0.082\end{array}$ & $\begin{array}{c}239 \\
0.013\end{array}$ & $\begin{array}{c}510 \\
0.340\end{array}$ \\
\hline
\end{tabular}

Significant level: * $0.1 * * 0.05 * * * 0.01$

Standard Errors are clustered by institutions

22 
Table A5: Satisfaction French Institutions

\begin{tabular}{lcccccc}
\hline \hline & \multicolumn{2}{c}{$(1)$} & \multicolumn{2}{c}{$(2)$} & \multicolumn{2}{c}{$(3)$} \\
& \multicolumn{2}{c}{ IDF } & \multicolumn{2}{c}{ Burgundy } & \multicolumn{2}{c}{ ttest } \\
& mean & sd & mean & sd & b & se \\
\hline Satisfaction & 0.49 & 0.23 & 0.63 & 0.23 & $0.13^{* * *}$ & $(0.03)$ \\
Preference Online & 0.17 & 0.24 & 0.14 & 0.22 & -0.03 & $(0.03)$ \\
Effective Time & 0.46 & 0.21 & 0.58 & 0.29 & $0.12^{* * *}$ & $(0.03)$ \\
\hline Observations & 162 & & 109 & & 271 & \\
\hline \hline
\end{tabular}

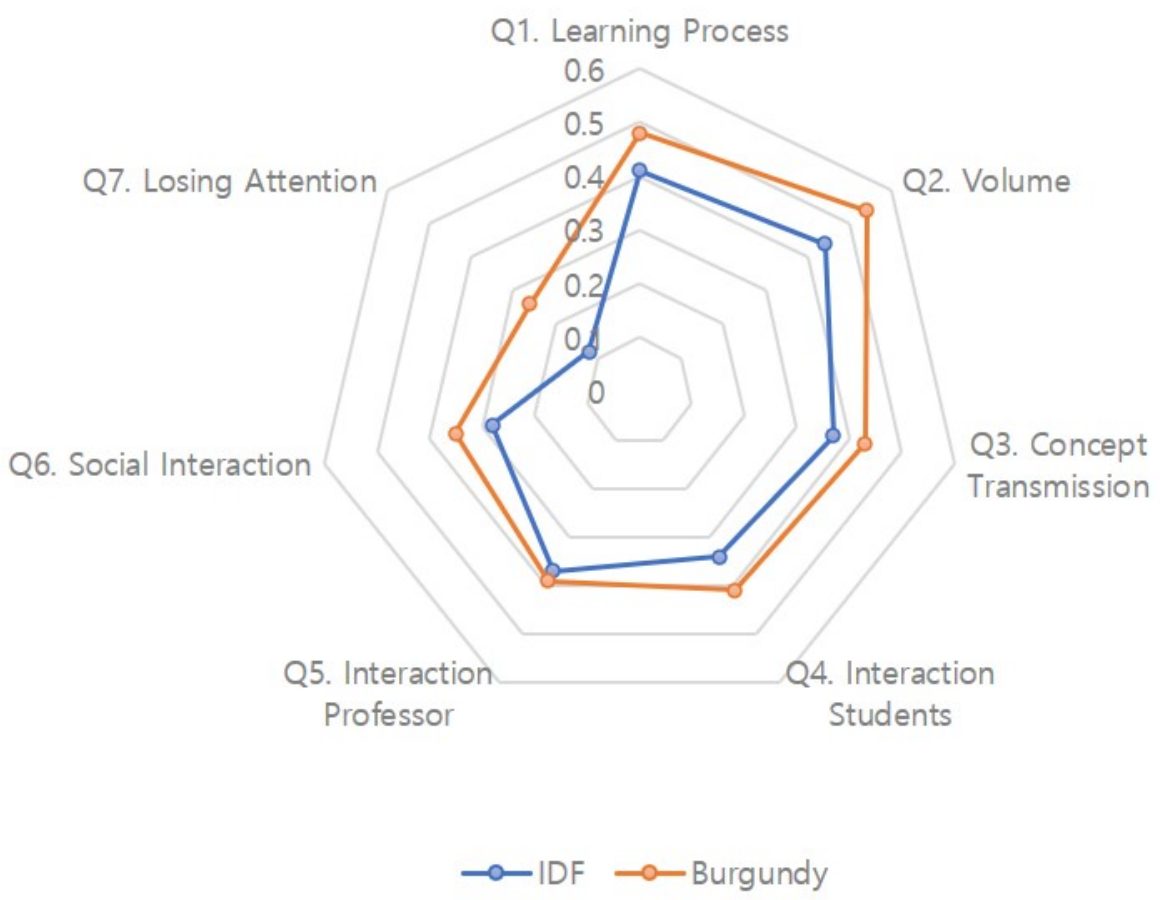

Figure A1: Components of Satisfaction with Online Teaching: French Institutions 


\section{I \\ ESSEC \\ BUSINESS SCHOOL}

ESSEC Business School

3 avenue Bernard-Hirsch

CS 50105 Cergy

95021 Cergy-Pontoise Cedex

France

Tel. +33 (0)134433000

www.essec.edu

\section{ESSEC Executive Education}

CNIT BP 230

92053 Paris-La Défense

France

Tel. +33 (0)1 46924900

www.executive-education.essec.edu

\section{ESSEC Asia-Pacific}

5 Nepal Park

CONTACT:

Singapore 139408

RESEARCH CENTER

Tel. +65 68849780

research@essec.edu

\section{www.essec.edu/asia}

ESSEC | CPE Registration number 200511927D

Period of registration: 30 June 2017 - 29 June 2023

Committee of Private Education (CPE) is part of SkillsFuture Singapore (SSG)

\section{ESSEC Africa}

Plage des Nations - Golf City

Route de Kênitra - Sidi Bouknadel (Rabat-Salê)

Morocco

Tel. +212 (0)537824000

www.essec.edu 